\title{
Sorghum Seedling Drought Response: In Search of Tolerant Genotypes
}

\author{
Irawati Chaniago", Auzar Syarif ${ }^{\#}$, Putri Riviona ${ }^{\#}$ \\ ${ }^{\#}$ Department of Agroecotechnology, Universitas Andalas, Kampus Limau Manis, Padang, 25163, Indonesia \\ E-mail: irawatiunand64@gmail.com,auzar_syarif@yahoo.com,riviona_putri@yahoo.com
}

\begin{abstract}
Drought stress is a major factor contributing disease susceptibility and yield loss in agricultural crops. The experiment reported here was aimed at studying the germination and early growth of ten sorghum (Sorghum bicolor L. Moench) genotypes in 0 or $20 \%(w / v)$ polyethylene glycol (PEG 6000) solution as a model to mimic drought stress. The experiment was carried out at the Laboratory of Seed Technology and a glass house of Faculty of Agriculture, Universitas Andalas Padang from March to April 2015. A two-way factorial experiment in a completely randomised design with three replicates was assigned. Data were analysed with analysis of variance and mean comparisons of Duncan's New Multiple Range Test at $5 \%$ level. When only PEG was found to be significant, then mean comparisons was calculated according to t-Dunnet test. Sorghum seeds were germinated on two layers of Whatmann paper in Petri dishes either in $0 \%$ or $20 \%$ PEG for seven days prior to transfer into Hoagland solution containing 0 or $20 \%$ PEG with a layer of paraffin wax for 21 days in a glass house. Results indicated that $20 \%$ PEG solution reduced seedling dry weight and the length or roots protruding from the paraffin wax layer in some genotypes. Sorghum genotype No. 5 was more tolerant to drought stress in their early growth followed by genotypes Samurai 2, Samurai Batan, and Pahat Batan. In contrast, genotypes Advanta and No. 44 were found to be the most susceptible.
\end{abstract}

Keywords — drought; early growth; polyethylene glycol (PEG); sorghum

\section{INTRODUCTION}

Sorghum, commonly grown for the production of sugar, is the fifth most important grain crop in the world, and the primary food source for people in many developing countries. It is one of cereals crop with high potential to be cultivated in Indonesia for a wide range of agroclimatic. This crop is tolerant to drought and grows fairly well in poor soil and relatively resistant to pest and diseases. Sorghum is known for its 5F function. They are Food, Feed, Fibre, Fuel, and Fertiliser. This broad spectrum function, however, has not put sorghum into important major crops in Indonesia. In addition, Indonesia has to make best efforts to diversify food sources for the growing population and not burdening rice as its major source of carbohydrate. However, sorghum yields have not increased or have even declined because production is being pushed into more marginal areas and poorer soils. In addition, drought may be the most important abiotic stress limiting crop productivity worldwide [1].

Climate change has emerged as an obstacle to the development of agriculture worldwide. Changes in temperature, the amount of carbon dioxide $\left(\mathrm{CO}_{2}\right)$, and the frequency and intensity of extreme weather, such as floods and drought, have had significant impacts on crop yields.
Global climate change is also likely altering the patterns of precipitation, which may increase soil and atmospheric water stresses [2]. These changes frequently exposed plants to a variety of abiotic stresses such as drought stress, which hamper plant growth and crop productivity worldwide [3] leaving drought stress as one of the premier limitations to agricultural production.

Environmental factors such as increasing temperature and drought continue to restrain crop production levels as they have in earlier decades. In many major-food-producing countries, this situation is predicted to worsen with changing climates [4], [5]. Drought is the most important abiotic stress and the main cause of significant losses in growth and productivity of crop plants [6], [7]. Drought tolerance is a complex plant property because it is a combination of the complexity of physiological, morphological and molecular traits. Developing food crop cultivars that can grow well under heat and drought is an important goal throughout the world.

Drought stress can be lethal to plants and lead to enormous social problems and economic losses. Drought causes not only serious agricultural production losses but also contributes to ecological damage, land desertification and soil erosion. Therefore, drought stress has been considered as an urgent global and environmental problem. 
Water scarcity has attracted great concern and stimulated more and more research inputs on the fundamental science of the drought resistance of plants and the application of the acquired knowledge for developing water-saving and drought-resistant crops [8]. The relative yield performance of genotypes in drought-stressed and non-stressed environments appear to be a common starting point for identifying desirable genotypes for unpredictable rainfall conditions [9].

The improvement of tolerance to drought has been a longlasting principal goal of the majority of breeding programs. Drought stress in certain stages of plant growth commonly occurs in many regions of the world [10]. In the studies on watering plants, increased emphasis is being placed on understanding reactions to drought, not only in species but also their particular varieties [11]. Different varieties can display various requirements in terms of environmental conditions [12]. The plant varieties with lower water requirements and/or higher resistance to drought could be useful in the areas with limited access to water and thus compensate the losses associated with reduced yields [13]. The effects of drought can be mitigated through plant breeding to create cultivars adapted to new climatic conditions and resistant to evolving pests and diseases. Drought tolerant crops, such as sorghum, need to be better exploited to reduce the impact of climate changes [14]. Water shortage can damage field crops anytime throughout the season, especially during the dry season yet the effect on seedling stage has received little attention.

The plant responds to drought stress by integrating various responses and adaptive mechanisms at the morphological, physiological, and molecular levels. However, different plant species or genotypes within a species often have large variations in the utilization of these mechanisms. At the early stage of water deficit, plants usually have an ability to absorb water from the underground efficiently through the root system, partially close stomata to reduce water loss from transpiration and modify the metabolism to match with the available carbon resource [15], [16]. As stress conditions increase, some osmolytic compounds such as prolines, soluble sugars, spermines, and betaine accumulate in plant cells to keep the cell turgor pressure [17].

The research reported here was aimed at studying the germination and early growth of ten sorghum genotypes in 0 and $20 \%(\mathrm{w} / \mathrm{v})$ polyethylene glycol (PEG 6000) solution in an attempt to screen sorghum genotypes potential to be grown in the marginal and dry land of the Province of West Sumatra.

\section{MATERIAL AND METHOD}

\section{A. Plant Culture Management}

The experiment was carried out at the Laboratory of Seed Technology and a glass house of Faculty of Agriculture, Universitas Andalas Padang from March to April 2015. Seeds of ten sorghum genotypes were obtained from Seed collection of the Laboratory of Agronomy, Universitas Andalas, Padang and from Indonesian Research Center for Cereal Crops, Maros, South Sulawesi. Ten seed were germinated on two layers of Whatmann paper in Petri dish with PEG solution. Two different polyethylene glycol (PEG 6000, Sigma-Aldrich, Steinheim, Germany) treatments were used to wet the germination media. Those were: $0 \%$ (control) and $20 \%(\mathrm{w} / \mathrm{v})$ PEG levels equivalent to 6.7 bars. Seed germination process took place for 7 days in a germination chamber.

The next step was transferring the sorghum seedlings onto pots for observation of root growth. A mixture of $70^{\circ} \mathrm{C}$ preheated paraffin and vaseline $(6: 4, w / w)$ was poured into a perforated base $240-\mathrm{mL}$ plastic pot. The mixture was then set to dry leaving a 3-mm thick layer equal to 12 bars [18] at the base of the pot. The pots were then filled with $200 \mathrm{~g}$ of soil and sand mixture $(1: 1 \mathrm{w} / \mathrm{w})$ prior to sorghum seedling transplanting. Two uniform seedlings with $1-\mathrm{cm}$-long radicle were planted per pot. The pots were then placed on a wooden rack in a glass house. The pots were individually stacked on another pot containing $45 \mathrm{~mL}$ Hoagland's nutrient solution. The pots were carefully placed so that the base of upper pots did not touch the nutrient solution in the lower pot. The seedlings were watered every day for $7 \mathrm{~mL}$ per pot. The experimental units were arranged according to a completely randomised design with three replicates per treatment for each of the 10 genotypes. An individual plant was considered as a single replicate as root variables were measured in individual plants.

\section{B. Measurement and Data Collection}

Data were recorded on 21 days after transplanting by destructive harvest. Observation includes plant height, length, and the number of roots protruding from the paraffin layer, shoot dry weight (following $70^{\circ} \mathrm{C} 48$ hours oven dried), stress tolerant index, and leaf proline content. Data were analysed by analysis of variance and means were separated using Duncan's New Multiple Range Test at 5\% level. When only PEG was found to be significant, then mean comparisons was calculated according to t-Dunnet test.

Proline content was measured as follow: about $0.5 \mathrm{~g}$ of leaves was extracted with $0.5 \mathrm{~mL}$ of $3 \% 5$-sulphosalicylic acid for $15 \mathrm{~min}$. Then the samples were centrifuged at $21,000 \times g$ for $15 \mathrm{~min}$. The clear supernatant was collected into a vial. The $4 \mathrm{~mL} 5$-sulphosalicylic acid was added to the residue and mixed before a second centrifuge. The first and second supernatant was thoroughly mixed. Two $\mathrm{mL}$ of the supernatant was mixed with $2 \mathrm{~mL}$ of $3 \%$ ninhydrin reagent and $2 \mathrm{~mL}$ of acetic glacial. The mixture was heated for $1 \mathrm{~h}$ at $100{ }^{\circ} \mathrm{C}$ in a water-bath and then cooled in an ice bath. Then $4 \mathrm{~mL}$ of toluene was added to the mixture and mixed for 15 seconds prior to absorbance measurement at $520 \mathrm{~nm}$ in a spectrophotometer. The level of proline was expressed in $\mu \mathrm{M} / \mathrm{g} \mathrm{FW}$ (fresh weight of leaves).

Tolerance index was obtained using the following equation:

$$
\mathrm{TI}=\frac{r_{d}}{r_{n}} \times \frac{Y d}{H y d}
$$

where $Y d$ and $Y n$ respectively represent observed variable under drought and normal condition. Hyd is the highest observed variable under drought condition. TI $>0.5=$ tolerant and $\mathrm{TI}<0.5=$ susceptible. 


\section{RESULTS AND DISCUSSION}

Different sorghum genotypes responded differently to PEG and 20\% PEG resulted in reduced plant height in some genotypes. The difference in plant height (Table 1) in response to drought stress confirmed variation in plant utilisation of the mechanisms including physiological, morphological, and molecular levels.

Growth and development processes in plants are generally very vulnerable to water scarcity [19] and may lead to significant increase in electrolyte leakage from leaves. Maintaining a high water content provides an opportunity not only to protect physiological processes during drought better but also to improve recovery of plants after rewatering. Maintaining a high value of this parameter during drought provides an opportunity not only to protect physiological processes better but also to improve plant recovery after re-watering. This may happen when water deficit has not reached to the permanent wilting point. Reference [20] reported that water shortage in the soil causes a reduction in the growth of wheat leaf area by an average of $30 \%$ and a reduction in the dry weight of wheat seedlings by $19 \%$. This finding confirmed that drought stress affects physiological function leading to growth retardation in plants.

TABLE I

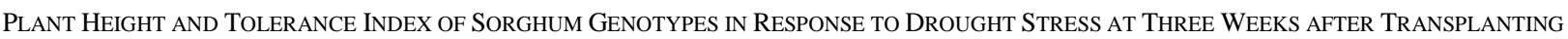

\begin{tabular}{|l|c|c|c|l|c|}
\hline \multirow{2}{*}{ Genotype } & \multicolumn{2}{|c|}{ Plant height $(\mathbf{c m})$} & \multirow{2}{*}{$\begin{array}{c}\text { Tolerance } \\
\text { Index }\end{array}$} & Remarks & $\begin{array}{c}\text { Resistance } \\
\text { Probability (\%) }\end{array}$ \\
\cline { 2 - 3 } & PEG 20\% & PEG 0\% & & 25.78 \\
\hline Advanta & $0.00 \mathrm{~B} \mathrm{i}$ & $32.78 \mathrm{~A} \mathrm{~h}$ & 0.00 & Susceptible & 63.31 \\
\hline Samurai 2 & $61.05 \mathrm{~A} \mathrm{a}$ & $59.26 \mathrm{~B} \mathrm{~cd}$ & 1.03 & Tolerant & 55.96 \\
\hline Samurai Batan & $54.04 \mathrm{~B} \mathrm{bc}$ & $56.63 \mathrm{~A} \mathrm{de}$ & 0.84 & Tolerant & 57.93 \\
\hline Halaban 50 Kota & $50.69 \mathrm{~B} \mathrm{~cd}$ & $54.18 \mathrm{~A} \mathrm{ef}$ & 0.78 & Tolerant & 53.19 \\
\hline Pahat Batan & $43.58 \mathrm{~A} \mathrm{ef}$ & $41.65 \mathrm{~B} \mathrm{~g}$ & 0.75 & Tolerant & 50.40 \\
\hline No. 5 & $59.00 \mathrm{~B} \mathrm{a}$ & $63.39 \mathrm{~A} \mathrm{bc}$ & 0.90 & Tolerant & 37.83 \\
\hline No. 44 & $12.75 \mathrm{~B} \mathrm{~h}$ & $65.99 \mathrm{~A} \mathrm{ab}$ & 0.04 & Susceptible & 50.00 \\
\hline Sumanik T. Datar & $29.31 \mathrm{~B} \mathrm{~g}$ & $32.79 \mathrm{~A} \mathrm{~h}$ & 0.43 & Susceptible & 48.80 \\
\hline No. 41 & $41.88 \mathrm{~B} \mathrm{f}$ & $51.25 \mathrm{~A} \mathrm{f}$ & 0.56 & Tolerant & 47.61 \\
\hline No. 38 & $47.15 \mathrm{~B} \mathrm{de}$ & $69.57 \mathrm{~A} \mathrm{a}$ & 0.52 & Tolerant & \\
\hline
\end{tabular}

Means of plant height followed by same capital letter within the row and means followed by same small letter within the column are not significantly different

TABLE II

SHOOT DRY WEIGHT AND TOLERANCE INDEX PF SORGHUM GENOTYPES IN RESPONSE TO DROUGHT STRESS AT THREE WEEKS AFTER TRANSPLANTING

\begin{tabular}{|c|c|c|c|c|c|}
\hline \multirow{2}{*}{ Genotype } & \multicolumn{2}{|c|}{ Shoot dry weight (mg) } & \multirow{2}{*}{$\begin{array}{c}\text { Tolerance } \\
\text { Index }\end{array}$} & \multirow{2}{*}{ Remarks } & \multirow{2}{*}{$\begin{array}{c}\text { Resistance } \\
\text { Probability (\%) }\end{array}$} \\
\hline & PEG 20\% & PEG 0\% & & & \\
\hline Advanta & $0,000 \quad \mathrm{~B} \quad \mathrm{~h}$ & 72.5 A f & 0.00 & Susceptible & 49,6 \\
\hline Samurai 2 & $99.5 \quad \mathrm{~B} \quad \mathrm{e}$ & $172.0 \quad \mathrm{~A} \quad \mathrm{~b}$ & 0.26 & Susceptible & 48,8 \\
\hline Samurai Batan & $122.8 \quad \mathrm{~B} \quad \mathrm{~cd}$ & $163.5 \mathrm{~A} \mathrm{bc}$ & 0.42 & Susceptible & 50,0 \\
\hline Halaban 50 Kota & $221.4 \quad \mathrm{~A} \mathrm{a}$ & 217.9 A a & 1.02 & Tolerant & 50,4 \\
\hline Pahat Batan & $156.8 \mathrm{~A} \quad \mathrm{~b}$ & 90.1 B ef & 1.23 & Tolerant & 50,4 \\
\hline No. 5 & $100.7 \mathrm{~A} \mathrm{de}$ & 70.6 B $\quad f$ & 0.65 & Tolerant & 50,4 \\
\hline No. 44 & 48.2 B $\quad \mathrm{g}$ & 114.9 A d & 0.09 & Susceptible & 49,2 \\
\hline Sumanik T. Datar & $129.5 \quad \mathrm{~A} \quad \mathrm{c}$ & $121.5 \quad \mathrm{~A} \quad \mathrm{~d}$ & 0.62 & Tolerant & 50,4 \\
\hline No. 41 & 50.9 B $\quad$ fg & $124.8 \mathrm{~A} \mathrm{~d}$ & 0.09 & Susceptible & 49,6 \\
\hline No. 38 & $86.4 \quad \mathrm{~B} \quad \mathrm{e}$ & 138.1 A cd & 0.24 & Susceptible & 48,4 \\
\hline
\end{tabular}

Means of shoot dry weight followed by same capital letter within the row and means followed by same small letter within the column are not significantly different

At the early stage of water deficit, plants usually have an ability to absorb water from the underground efficiently through the root system, partially close stomata to reduce water loss from transpiration and modify the metabolism to match with the available carbon resource [15], [16]. However, our finding showed that sorghum variety Advanta did not grow when exposed to $20 \%$ PEG. In contrast, sorghum var Samurai 2 demonstrated the highest plant height and was significantly different to other varieties but genotype No. 5. Three genotypes, Advanta, No. 44, and Sumanik T. Datar, were found to be vulnerable to drought stress according to tolerance index of plant height.
Variation in shoot dry weight was observed in sorghum both in PEG 20\% treatment group or control treatment group (Table 2). Sorghum genotype No. 44 consistently affected by the treatment as demonstrated by its lower plant height and dry shoot weight. However, other genotypes responded differently to the observation of both plant height and dry shoot weight. Reduction in shoot dry weight in response to $20 \%$ of PEG was observed in genotypes Advanta, Samurai 2, Samurai Batan, No. 44, No. 41, and No. 38. The reduction was ranging from $25-100 \%$ and resulted in classifying those genotypes as susceptible to drought stress reported here. 
Reference [20] reported that drought stress resulted in significantly lower growth vigor of wheat seedlings. Growth measured as leaf area and mass accumulation of whole plants were inhibited. The mean value of relative growth rate of leaf area (RGRa) decreased in the varieties tested during the period of stress by nearly $40 \%$, while the intensity of net assimilation ratio (NAR) by about $10 \%$. Drought caused differences in the varieties tested in all parameters of growth measured between 20 varieties of wheat in Poland.

Various research has been carried out to find crop genotypes tolerant to drought. However, drought screening yield trial environments can be very different depending on the onset of stress, humidity, residual soil moisture, etc. [21], [22]. It is possible that this field study simply did not have the right type of drought stress or intense enough stress to correlate seedling drought tolerance with yield. Crop yield under drought stress is a highly quantitative trait in part because there are many contributing mechanisms and secondary traits [23] in plant response to abiotic stress in the field.

Roots become the first organ in plants that are exposed to drought stress in the soil. Research reported here observed that drought stress resulted in most of the genotypes tested except for Samurai 2, Pahat Batan, Sumanik T. Datar, and No. 38. Root length is protruding from the paraffin layer ranging from 1.09 to $5.83 \mathrm{~cm}$ (Table 3). A slightly different observation was noted in the number of roots protruding from the paraffin layer. Some genotypes were categorized tolerant to the drought stress treatment with the value of resistance probability ranging from 48.8 to $54.30 \%$ (Table 4). Drought-tolerant soybean genotypes develop deep rooting phenotype with a root angle of $40^{\circ}-60^{\circ}$ under field experiment. The soybean cultivar demonstrated greatest shoot biomass and grain yield under limited water availability [24]. This is in line with data reported here that sorghum genotypes Samurai 2 and Pahat Batan had longer root protruding from the paraffin layer in drought stress treatment compared to that of grown in control treatment group. These two genotypes are classified into tolerant genotypes with tolerance index are 0.84 and 1.00; respectively. Reference [24] reported that the distribution of roots, particularly those that can penetrate deeper into the soil, plays a crucial role in determining the ability of plants to capture key resources such as water and mobile nutrients from the soil. Root architecture, therefore, has a major effect on the growth and yield of crop plants.

TABLE III

LENGTH of Root Protruding From the PARAFFin LAyer AND TOLERANCE INDEX OF SORGHUM GENOTyPES IN ReSPONSE TO DROUGHT STRESS AT THREE WEEKS AFTER TRANSPLANTING

\begin{tabular}{|c|c|c|c|c|c|}
\hline \multirow{2}{*}{ Genotype } & \multicolumn{2}{|c|}{ Root length (cm) } & \multirow{2}{*}{$\begin{array}{l}\text { Tolerance } \\
\text { Index }\end{array}$} & \multirow{2}{*}{ Remarks } & \multirow{2}{*}{$\begin{array}{c}\text { Resistance } \\
\text { Probability }(\%)\end{array}$} \\
\hline & PEG 20\% & PEG 0\% & & & \\
\hline Advanta & $0,00 \quad \mathrm{~B} \quad \mathrm{f}$ & $1,09 \quad \mathrm{~A} \quad \mathrm{fg}$ & 0.00 & Susceptible & 49.60 \\
\hline Samurai 2 & $3,85 \quad \mathrm{~A} \quad \mathrm{c}$ & $3,78 \quad \mathrm{~B} \quad \mathrm{c}$ & 0.84 & Tolerant & 51.99 \\
\hline Samurai Batan & $3,61 \quad \mathrm{~B} \quad \mathrm{~cd}$ & 5,83 A $\quad$ a & 0.77 & Tolerant & 50.40 \\
\hline Halaban 50 Kota & 0,00 B $\quad f$ & 2,27 A efg & 0.00 & Susceptible & 49.60 \\
\hline Pahat Batan & $4,67 \quad$ A $\quad$ a & $0,00 \quad \mathrm{~B} \quad \mathrm{~g}$ & 1.00 & Tolerant & 49.60 \\
\hline No. 5 & $3,36 \quad \mathrm{~A} \quad \mathrm{de}$ & $3,36 \quad$ A def & 0.72 & Tolerant & 50.00 \\
\hline No. 44 & $1,14 \quad \mathrm{~B} \quad$ ef & 3,58 A cde & 0.24 & Susceptible & 49.20 \\
\hline Sumanik T. Datar & $2,27 \quad \mathrm{~A}$ ef & $1,09 \quad \mathrm{~B} \quad \mathrm{fg}$ & 0.49 & Susceptible & 5.00 \\
\hline No. 41 & 2,23 B ef & 3,62 A $\mathrm{cd}$ & 0.48 & Susceptible & 5.00 \\
\hline No. 38 & $4,19 \quad \mathrm{~A} \quad \mathrm{~b}$ & $4,14 \quad \mathrm{~B} \quad \mathrm{~b}$ & 0.90 & Tolerant & 5.39 \\
\hline
\end{tabular}

Means of length of root protruding from paraffin layer followed by same capital letter within the row and means followed by same small letter within the column are not significantly different

TABLE IV

Number of Root Protruding From the PARAFFin LAYER AND TOLERANCE INDEX OF SORGHUM GENOTYPES IN RESPONSE TO DROUGHT STRESS AT THREE WEEKS AFTER TRANSPLANTING

\begin{tabular}{|c|c|c|c|c|c|}
\hline \multirow{2}{*}{ Genotype } & \multicolumn{2}{|c|}{ Number of root } & \multirow{2}{*}{$\begin{array}{l}\text { Tolerance } \\
\text { Index }\end{array}$} & \multirow{2}{*}{ Remarks } & \multirow{2}{*}{$\begin{array}{c}\text { Resistance } \\
\text { Probability (\%) }\end{array}$} \\
\hline & PEG 20\% & PEG 0\% & & & \\
\hline Advanta & $0.00 \mathrm{~B}$ & $1.00 \mathrm{~A}$ & 0.00 & Susceptible & 49.60 \\
\hline Samurai 2 & $6.21 \quad \mathrm{~A}$ & $5.41 \quad \mathrm{~B}$ & 1.15 & Tolerant & 54.38 \\
\hline Samurai Batan & $5.14 \quad \mathrm{~A}$ & $5.73 \mathrm{~A}$ & 0.74 & Tolerant & 50.00 \\
\hline Halaban 50 Kota & $0.00 \mathrm{~B}$ & $2.82 \mathrm{~A}$ & 0.00 & Susceptible & 49.60 \\
\hline Pahat Batan & $6.48 \mathrm{~A}$ & $0.00 \quad \mathrm{~B}$ & 0.00 & Susceptible & 49.60 \\
\hline No. 5 & $4.55 \mathrm{~A}$ & $4.55 \mathrm{~A}$ & 0.73 & Tolerant & 50.00 \\
\hline No. 44 & $1.41 \mathrm{~B}$ & $6.00 \mathrm{~A}$ & 0.05 & Susceptible & 48.80 \\
\hline Sumanik T. Datar & $3.46 \quad \mathrm{~A}$ & $1.41 \mathrm{~B}$ & 1.37 & Tolerant & 51.20 \\
\hline No. 41 & $3.14 \mathrm{~A}$ & $2.82 \mathrm{~A}$ & 0.56 & Tolerant & 50.00 \\
\hline No. 38 & $5.97 \mathrm{~A}$ & $5.73 \mathrm{~A}$ & 1.00 & Tolerant & 53.19 \\
\hline
\end{tabular}

Means of number of root followed by same capital letter within the row are not significantly different 
Different types of drought resistance strategies have evolved in and allow plants to adapt to specific environmental conditions. Drought resistance is defined as the integrated capability of plants in response and adaption to the harsh environment caused by drought stress conditions. This capability is a sophisticated trait and is related to the adaptations at different levels, ranging from plant morphology and anatomical structures to physiological and biochemical reactions [25].

TABLE V

PROLINE CONTENT OF SORGHUM GENOTYPES IN RESPONSE TO DROUGHT STRESS AT THREE WEEKS AFTER TRANSPLANTING

\begin{tabular}{|l|c|c|}
\hline \multirow{2}{*}{\multicolumn{1}{|c|}{ Genotype }} & \multicolumn{2}{c|}{ Proline content $(\mu \mathrm{M} / \mathrm{g}$ FW) } \\
\cline { 2 - 3 } & PEG 20\% & PEG 0\% \\
\hline Advanta & 0.00 & 5.69 \\
\hline Samurai 2 & 4.85 & 5.10 \\
\hline Samurai Batan & 4.81 & 4.64 \\
\hline Halaban 50 Kota & 5.46 & 7.93 \\
\hline Pahat Batan & 4.81 & 4.64 \\
\hline No. 5 & 4.91 & 8.14 \\
\hline No. 44 & 4.21 & 5.62 \\
\hline Sumanik T. Datar & 3.35 & 3.36 \\
\hline No. 41 & 6.94 & 6.18 \\
\hline No. 38 & 4.04 & 4.87 \\
\hline
\end{tabular}

Plant drought resistance is quite a complex trait and mechanism. The plant often combines different categories of mechanisms to confer drought resistance at different developmental stages. At a particular developmental stage, plant drought resistance is associated with a series of events such as stomatal movement, photosynthesis, cell osmotic regulation, synthesis of protective macromolecules and antioxidants. Consequently, the determination of drought resistance is much more difficult and complex than that of other stress resistances [26].

Proline has been known as one of osmoprotectant compound found effective in mitigating drought stressinduced damage in plants [27]. Different but nonsignificant proline content was observed in sorghum genotypes in response to drought stress in the 20\% PEG treatment group (Table 5). Genotypes Samurai Batan, Pahat Batan, and No. 41 responded to $20 \%$ PEG through increasing the level of proline in leaves whilst other genotypes responded vice versa.

Reference [28] reported that after PEG treatment, proline content in wheat was found six times higher than that of control treatment group. Supplementation of medium with salicylic acid (SA) and abscisic acid (ABA) increased proline content only for drought resistant wheat cultivar, though the increase was observed more in the SAsupplemented group. It is well known that proline accumulates in plants during adaptation to various types of environmental stresses including drought. Different roles have been proposed for proline accumulation, and their data supports the notion that proline accumulation in stressed plants plays a protective role.

Drought tolerant-associated indicators mainly cover physiological parameters related to osmotic adjustments (OA) such as osmotic potential, proline content, and ABA content and alleviation of drought damage such as the activities of protective enzymes and chlorophyll content. Some complex mechanisms and traits relevant to biomass or economic yield under stress conditions are also used to evaluate the drought resistance of crops in agricultural production. These traits include biomass accumulation, survival rate, stay-green capability, seed-setting rate, spikelet fertility, grain weight, and so forth. These traits are more meaningful and effective in breeding for drought resistance, although they have seldom been used to unveil the mechanisms of drought resistance at the physiological and molecular levels [25]. In addition to induction or activation of enzymes of proline biosynthesis or decreased proline oxidation to glutamate, proline accumulation under stress conditions may result from decreased utilization of proline in protein synthesis and enhanced protein turnover [29].

Oxidative stress commonly occurs along with drought stress. Plants characteristically respond to drought stress by rapid production of reactive oxygen species (ROS) including superoxide radicals $\left(\mathrm{O}_{2}^{-}\right)$, hydrogen peroxide $\left(\mathrm{H}_{2} \mathrm{O}_{2}\right)$, and hydroxyl radicals $(\mathrm{OH})$ which may lead to lethal damage to the plant tissues [30]. Under normal circumstances, the intracellular generation and removal of ROS are under dynamic equilibrium. When plants suffer from exposure to drought stress conditions, the dynamic equilibrium is broken, and the excessive accumulation of ROS injures cells, and the oxidative deterioration may ultimately lead to cell death [26]. The membrane phospholipids and fatty acids which are sensitive to the over-accumulation of ROS are damaged, resulting in the peroxidation of membrane lipids [31]. Under ROS stress, the spatial configurations of various membrane proteins or enzymes are disturbed, leading to increased membrane permeability and ion leakage, chlorophyll destruction, metabolism perturbations, and even severe injury or death to plants [32].

\section{CONCLUSIONS}

Some sorghum genotypes demonstrated a reduction in seedling dry weight and the length or roots protruding from the paraffin wax layer in response to $20 \%$ PEG solution. Genotype No. 5 was more tolerant to drought stress in their early growth followed by genotypes Samurai 2, Samurai Batan, and Pahat Batan. In contrast, genotypes Advanta and No. 44 were found to be the most susceptible.

\section{ACKNOWLEDGMENT}

This was a self-funded research, and we would like to thank the Laboratory of Agronomy, Andalas University, Padang and Indonesian Research Center for Cereal Crops, Maros, South Sulawesi for providing us with sorghum seeds.

\section{REFERENCES}

[1] Menezes, C.B., C.A. Ticona-Benavente, F.D. Tardin, M.J. Cardoso, E.A. Bastos, D.W. Nogueira, A.F. Portugal, C.V. Santos and R.E. Schaffert, "Selection indices to identify drought-tolerant grain sorghum cultivars", Genetics and Molecular Research, vol. 13, no. 4, pp. 9817-9827, 2014.

[2] Wang, W.F., Y.Z. Zong and S.Q. Zhang, "Water-and nitrogen-use efficiencies of sweet sorghum seedlings are improved under water stress". Int. J. Agric. Biol., vol. 16, pp. 285-292, 2014.

[3] Li, S.X. Dry Land Agriculture in China, Beijing, China: China Science Press, pp. 1-5, 2007. 
[4] Lobell, D.B., W. Schlenker, and J. Costa-Roberts, "Climate trends and global crop production since 1980", Science, vol. 333, p. 616, 2011.

[5] Mishra, V., and K.A. Cherkauer, "Retrospective droughts in the crop growing season: Implications to corn and soybean yield in the midwestern United States". Agric. For. Meteorol. Vol. 150, pp. 1030-1045, 2010

[6] Hasegawa, M., R. Bressan, and J. M. Pardo, "The dawn of plant salt tolerance genetics". Trends Plant Sci. vol. 5, pp. 317-319, 2000.

[7] Moussa, H.R. and S. M. Abdel-Aziz, "Comparative response of drought tolerant and drought sensitive maize genotypes to water stress". Aust. J. Crop Sci. vol. 1, pp. 31-36, 2008.

[8] Fang. Y and L. Xiong, "General mechanisms of drought response and their application in drought resistance improvement in plants", Cell. Mol. Life Sci. vol. 72, pp. 673-689, 2015.

[9] Mohammadi, R., M. Armion, D. Kahrizi, and A. Amri, "Efficiency of screening techniques for evaluating durum wheat genotypes under mild drought conditions". Int. J. Plant Prod. Vol. 4, pp. 11-24, 2010.

[10] Shao, H.B., Z.S. Liang, and M. A. Shao, "Changes of anti-oxidative enzymes and MDA content under soil water deficits among 10 wheat (Triticum aestivum L.) genotypes at maturation stage". Coll. Surf. B Biointerfaces, vol. 45, pp. 7-13, 2005

[11] Huseynova, I., and S. M. Rustanamova, "Screening for drought stress tolerance in wheat genotypes using molecular markers". Proc. ANAS Biol. Sci., vol. 65, pp. 132-139, 2010.

[12] Pantuwan, G., S. Fukai, M. Cooper, S. Rajatasereekul, and J. C. O'Toole, "Yield response of rice (Oryza sativa L) genotypes to drought under rained lowlands. II. Selection of drought resistant genotypes". Field Crop Res., vol. 73, pp. 169-180, 2002.

[13] Passioura, J. "The drought environment physical, biological and agricultural perspectives". J. Exp. Bot., vol. 5, pp. 113-117, 2007.

[14] Menezes, C.B., D.C. Saldanha, C.V. Santos, L.C. Andrade, M.P Mingote Júlio, A.F. Portugal and F.D. Tardin, "Evaluation of grain yield in sorghum hybrids under water stress", Genetics and Molecular Research, vol. 14, no. 4, pp. 12675-12683, 2015.

[15] Reddy, A. R., K. V. Chaitanya, and M. Vivekanandan, ”Droughtinduced responses of photosynthesis and antioxidant metabolism in higher plants". J. Plant Physiol. Vol. 161, pp.1189-1202, 2004.

[16] $\mathrm{Hu} \mathrm{H}$, and L. Xiong, "Genetic engineering and breeding of droughtresistant crops". Annu. Rev. Plant Biol., vol. 65, pp. 715-741, 2014.

[17] Seki, M., T. Umezawa, K. Urano, and K. Shinozaki, "Regulatory metabolic networks in drought stress responses". Curr. Opin. Plant Biol., vol. 10, pp. 296-302, 2007.

[18] Suardi, D., "Kajian metode skrining padi tahan kekeringan", Buletin Agrobio, vol. 3, no. 2, pp. 67-73, 2001.

[19] Oukarroum, A., S. El Madidi, G. Schansker, and R. J. Strasser, "Probing the responses of barley cultivars (Hordeum vulgare L.) by chlorophyll a fluorescence OLKJIP under drought stress and rewatering". Environ. Exp. Bot., vol. 60, pp. 438-446, 2007.

[20] Biesaga-Kościelniak, J., A. Ostrowska, M. Filek, M. Dziurka, P. Waligórski, M. Mirek, and J. Kościelniak, "Evaluation of spring wheat (20 varieties) adaptation to soil drought during seedlings growth stage", Agriculture, vol. 4, pp. 96-112, 2014.

[21] Campos, H., M. Cooper, J. Habben, G. Edmeades, and J. Schussler, "Improving drought tolerance in maize: A view from industry". Field Crops Res. vol. 90, pp. 19-34, 2004.

[22] Collins, N.C., F. Tardieu, and R. Tuberosa, "Quantitative trait loci and crop performance under abiotic stress: Where do we stand?", Plant Physiol. vol. 47, pp. 469-486, 2008.

[23] Meeks, M., S. C. Murray, S. Hague, and D." Measuring Maize Seedling Drought Response in Search of Tolerant Germplasm". Agronomy, vol. 3, pp. 135-147, 2013.

[24] Fenta, B. A., S. E. Beebe, K. J. Kunert, J. D. Burridge, K. M. Barlow, J. P. Lynch, and C. H. Foyer, "Field Phenotyping of Soybean Roots for Drought Stress Tolerance", Agronomy, vol. 4, pp. 418-435, 2014.

[25] Fang, Y. and L. Xiong, "General mechanisms of drought response and their application in drought resistance improvement in plants", Cell. Mol. Life Sci. vol. 72, pp. 673-689, 2015.

[26] Levitt, J., Responses of plants to environmental stresses, vol II. Water, radiation, salt, and other stresses. London: Academic Press, 1980.

[27] Yang, L., T. Jiang, J. C. Fountain, B. T. Scully, R. D. Lee, R. C Kemerait, S. Chen, and B. Guo, "Protein profiles reveal diverse responsive signaling pathways in kernels of two maize inbred lines with contrasting drought sensitivity", Int. J. Mol. Sci., vol. 15, pp. 18892-18918, 2014.

[28] Marcińska, I., I. Czyczyło-Mysza, E. Skrzypek, M. T. Grzesiak, F. Janowiak, M. Filek, M. Dziurka, K. Dziurka, P. Waligórski, K. Juzoń, K. Cyganek, and S. Grzesiak, " Alleviation of osmotic stress effects by exogenous application of salicylic or abscisic acid on wheat seedlings", Int. J. Mol. Sci. vol. 14, pp. 13171-13193, 2013

[29] Delauney, A. and D. P. S. Verma, "Proline biosynthesis and osmoregulation in plants". Plant J. vol. 4, pp. 215-223, 1993.

[30] Gill, S. S. and N. Tuteja, "Reactive oxygen species and antioxidant machinery in abiotic stress tolerance in crop plants". Plant Physiol. Biochem. vol. 48, pp. 909-930, 2010.

[31] Cruz, de.,M., "Drought stress and reactive oxygen species: production, scavenging and signaling". Plant Signal Behav., vol.3, pp. $156-165,2008$.

[32] Moller, I. M., "Plant mitochondria and oxidative stress: electron transport, NADPH turnover, and metabolism of reactive oxygen species". Ann. Rev. Plant Physiol. Plant Mol. Biol., vol. 52, pp. 561591, 2001. 